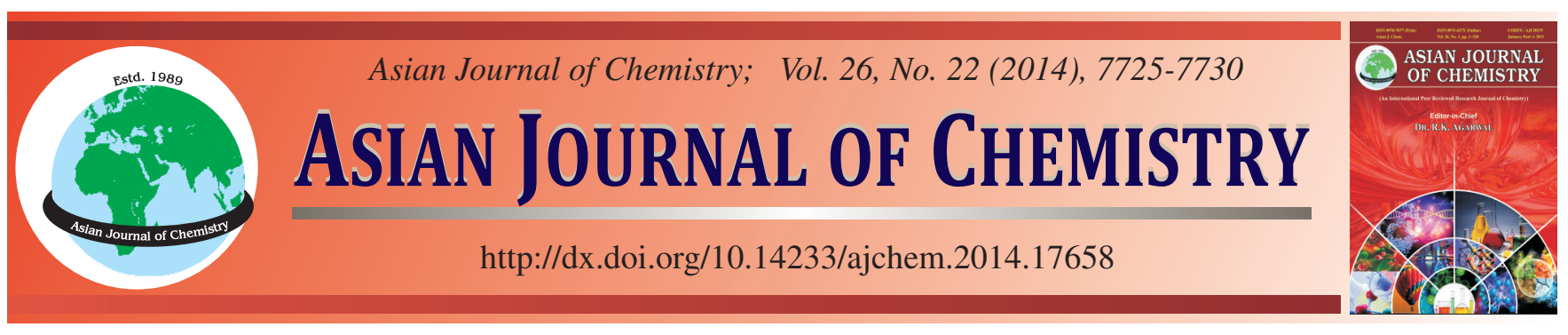

\title{
Synthesis and Biological Activity Evaluation of Novel Fasudil Derivatives
}

Hang Li ${ }^{1}$, Yifan DuAn ${ }^{2}$, Shende Jiang ${ }^{1}$, Ligong Chen $^{2}$ and Xilong YAN $^{2, *}$

${ }^{1}$ School of Pharmaceutical Science and Technology, Tianjin University, Tianjin 300072, P.R. China

${ }^{2}$ School of Chemical Engineering and Technology, Tianjin University, Tianjin 300072, P.R. China

*Corresponding author: Tel/Fax: +86 22 27406314; E-mail: yan@ @iju.edu.cn

\begin{abstract}
A series of isoquinoline Rho kinase inhibitors were designed and synthesized based on the ligand-binding pocket model with fasudil as the lead compound. Their biological activity including Rho kinsase inhibitory activity, cell viability were systematically evaluated on (3-[4,5-dimethyltyhiazol-2-yl]-2,5-diphenyl tetrazolium bromide) (MTT) assay and lactate deyhydrogenase (LDH) assay. Among these analogues, compounds $\mathbf{2}, 3$ and $\mathbf{6}$ not only exhibited Rho kinase inhibitory activity, but also promoted better cell viability. Therefore, they are potential candidates for the future drug discovery.
\end{abstract}

Keywords: (3-[4,5-Dimethyltyhiazol-2-yl]-2,5-diphenyl tetrazolium bromide) (MTT) assay and lactate deyhydrogenase (LDH) assay.

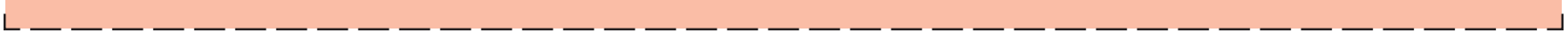

\section{INTRODUCTION}

Rho kinase, named Rho associated kinases, also known as Rho-associated coiled-coil forming protein serine kinase (ROCK), it plays a pivotal role in diverse cellular functions, including hypertension ${ }^{1}$, erectile dysfunction ${ }^{2}$, coronary and cerebral vasospasm ${ }^{3}$, glaucoma ${ }^{4,5}$, atherosclerosis ${ }^{6}$, asthma $^{7}$, multiple sclerosis $(\mathrm{MS})^{8}$, cancer $^{9}$, and stroke ${ }^{10}$. It has recently been reported that the Rho/Rho-kinase mediated pathway (Rho-kinase pathway) is involved in the pathogenesis of various cardiovascular disorders. In clinical situations, the Rhokinase pathway contributes to the occurrence of both epicardial and microvascular coronary artery spasm and the augmentation of peripheral vascular resistance in both patients with hypertension and normotensive current smokers ${ }^{10}$. So Rho kinases are now regarded as attractive, well-drugable targets and they provide new ways of developing therapeutic strategies for the treatment.

The ligand-binding pocket of the Rho kinase model was put forward, which is useful for developing new Rho kinase inhibitors with higher potency and selectivity. The ligandbinding pocket could be divided into three regions, region $\mathrm{A}$, F, D, as shown ${ }^{11}$ in Fig. 1. During the last two decades, Rho kinase inhibitors have been intensively studied ${ }^{11-16}$. Majority of works was focused on the combination mode of kinase with inhibitor at the bottom of the ligand-binding pocket (A region) and the effects of inhibitors to D region are rarely toughed. Fasudil, the only one marketed Rho kinase inhibitor, as a safe and clinically drug for treatment of cerebral vasospasm after subarachnoid hemorrhage, has also been examined for treatment of axonal loss in CIDP patients ${ }^{17,18}$. The obtained results are quite encouraging.

Then in our previous work, (S)-6H-1-(5-isoquinolinesulfonyl)-2-hydroxy -methyl-1-pyrrolidine displayed high inhibitory activity. Therefore, in this paper, we summarized our work on a new series of it isosteres and enantiomers, the Rho kinase inhibitory activities were evaluated and cell viability were systematically evaluated by MTT assay and LDH assay. We focus on to screen out Rho kinase inhibitors with better cell viability and significant inhibition activity simultaneously.

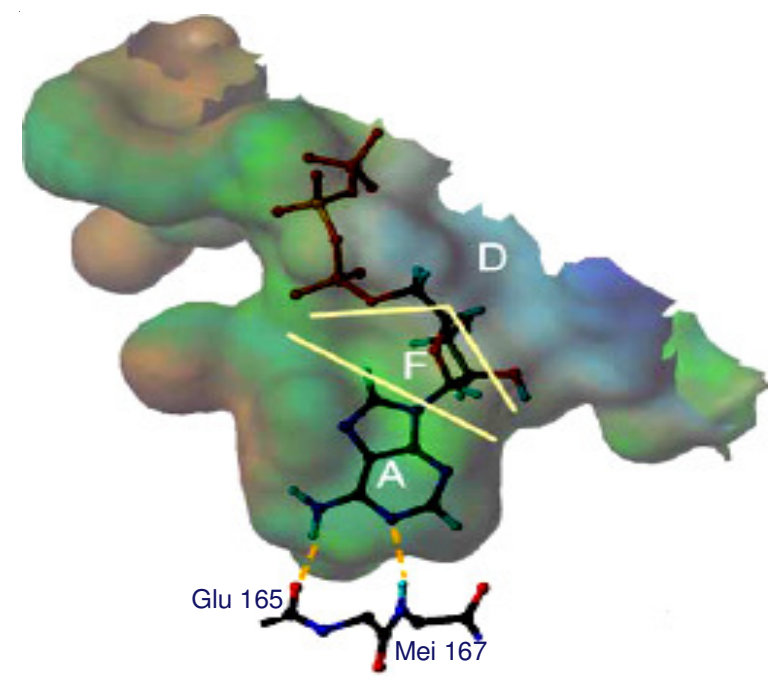

Fig. 1. Ligand-binding pocket of Rho kinase homology model [Ref. 11] 
EXPERIMENTAL

All the chemicals were purchased from Guangfu Technology Development Co., Ltd., Tianjin (China) and Chase Sun Pharmaceutical Co., Ltd., Tianjin (China) unless otherwise stated. All reagents were used as purchased from commercial suppliers without further purification. Solvents were dried and purified according to standard procedures before use. The course of reactions was monitored by TLC (silica gel GF254s), Flash chromatography was performed using 200 300 mesh silica gel. ${ }^{1} \mathrm{H}$ and ${ }^{13} \mathrm{C}$ NMR spectra were recorded on INOVA 400/600 Hz spectrometer with TMS as an internal standard. HR-MS was recorded on MicroOTOF-Q II.

Fasudil nitrogen oxides (1\#): Fasudil hydrochloride (5 g, $13.7 \mathrm{mmol}$ ) was slowly added to a saturated sodium bicarbonate solution $(2.50 \mathrm{~g}, 20 \mathrm{mmol})$, the $\mathrm{pH}$ of the solution was kept at 5-6. The mixture was stirred for $0.5 \mathrm{~h}$ and extracted with $80 \mathrm{~mL}$ of $\mathrm{CH}_{2} \mathrm{Cl}_{2}$. The organic layer was dried over anhydrous $\mathrm{Na}_{2} \mathrm{SO}_{4}$, filtered and concentrated. The M-chloroperoxybenzoic acid $(2.50 \mathrm{~g}, 14.5 \mathrm{mmol})$ was added dropwise to the organic layer in $35 \mathrm{~mL}$ dichloromethane. The reaction mixture was stirred at $30{ }^{\circ} \mathrm{C}$ for $1 \mathrm{~h}$. The organic layer was dried over anhydrous $\mathrm{Na}_{2} \mathrm{SO}_{4}$, filtered and concentrated. The crude was purified by flash chromatography (ethyl acetate) to afford compound $\mathbf{1}(4.49 \mathrm{~g}, 82.17 \%)$ yellow oil. ${ }^{1} \mathrm{H}$ NMR $\left(400 \mathrm{MHz} \mathrm{CDCl}_{3}\right) \delta: 9.42(\mathrm{~s}, 1 \mathrm{H}), 8.74(\mathrm{~s}, 2 \mathrm{H}), 8.49$ (d, $J=$ $7.3 \mathrm{~Hz}, 1 \mathrm{H}), 8.29$ (d, $J=8.1 \mathrm{~Hz}, 1 \mathrm{H}), 7.78(\mathrm{t}, J=7.8 \mathrm{~Hz}$, $1 \mathrm{H}), 3.97-3.82(\mathrm{~m}, 1 \mathrm{H}), 3.71(\mathrm{~d}, J=11.4,4.9 \mathrm{~Hz}, 2 \mathrm{H}), 3.56-$ $3.32(\mathrm{~m}, 2 \mathrm{H}), 1.99-1.70(\mathrm{~m}, 3 \mathrm{H}), 1.66-1.51(\mathrm{~m}, 1 \mathrm{H}) .{ }^{13} \mathrm{C}$ NMR $\left(100 \mathrm{MHz}, \mathrm{CDCl}_{3}\right) \delta: 14.79,21.38,25.13,30.53,61.78$, $104.15,127.04,129.33,131.52$, 134.22, 134.28, 136.16, 137.20, 173.24.

(S)-6H-1-(5-Isoquinolinesulfonyl)-2-hydroxymethyl-1pyrrolidine (2\#): Isoquinoline sulfonyl chloride hydrochloride ( $5 \mathrm{~g}, 18.9 \mathrm{mmol}$ ) was slowly added to a saturated sodium bicarbonate solution $(2.52 \mathrm{~g}, 30 \mathrm{mmol})$, the $\mathrm{pH}$ of the solution was kept at 5-6. The mixture was stirred $0.5 \mathrm{~h}$ and extracted with $20 \mathrm{~mL} \mathrm{CH} \mathrm{Cl}_{2}$. The organic layers were dried and concentrated. The residue dissolved in $20 \mathrm{~mL} \mathrm{CH}_{2} \mathrm{Cl}_{2}$ was added dropwise to the flask containing D-prolinol (2.29 g, $22.6 \mathrm{mmol})$ and triethylamine $(1.91 \mathrm{~g}, 18.9 \mathrm{mmol})$. The mixture was stirred at $0-5^{\circ} \mathrm{C}$ for $2 \mathrm{~h}$. Then it was concentrated and the residue was dissolved in $50 \mathrm{~mL}$ ethyl acetate. The organic layer was washed with $20 \mathrm{~mL}$ water for three times. After dried and concentrated, the residue was purified by flash chromatography (ethyl acetate) to afford compound 2 (5.29 g, $95 \%$ ) yellow oil. ${ }^{1} \mathrm{H}$ NMR $\left(400 \mathrm{MHz}, \mathrm{CDCl}_{3}\right) \delta: 9.42$ (s, $1 \mathrm{H}), 8.74$ (s, 2H), 8.49 (d, J=7.3 Hz, 1H), 8.29 (d, $J=8.1 \mathrm{~Hz}$, $1 \mathrm{H}), 7.78(\mathrm{t}, J=7.8 \mathrm{~Hz}, 1 \mathrm{H}), 3.97-3.82(\mathrm{~m}, 1 \mathrm{H}), 3.71(\mathrm{dd}, J=$ $11.4,4.9 \mathrm{~Hz}, 2 \mathrm{H}), 3.56-3.32$ (m, 2H), 1.99-1.70 (m, 2H), 1.66$1.51(\mathrm{~m}, 2 \mathrm{H}) .{ }^{13} \mathrm{C}$ NMR $\left(100 \mathrm{MHz}, \mathrm{CDCl}_{3}\right) \delta: 25.27,29.39$, 50.44, 62.70, 65.04, 124.31, 130.13, 131.35, 134.52, 136.42, $136.71,137.41,139.97,149.74$.

(S)-6H-1-(5-Isoquinolinesulfonyl)-2-chloromethyl-1pyrrolidine (3\#): Compound $\mathbf{2}$ ( $5 \mathrm{~g}, 0.02 \mathrm{~mol}$ ) was added to thionyl chloride $(20 \mathrm{~mL}, 0.27 \mathrm{~mol})$ and the reaction mixture was stirred at $40{ }^{\circ} \mathrm{C}$ for $8 \mathrm{~h}$. And then thionyl chloride was distilled. The saturated aqueous solution of sodium bicarbonate was added to keep the $\mathrm{pH}$ of the solution was 7-8. The residue was extracted with $60 \mathrm{~mL}$ of $\mathrm{CH}_{2} \mathrm{Cl}_{2}$. The crude was purified by flash chromatography (ethyl acetate) to afford compound $3(3.91 \mathrm{~g}, 75 \%)$ dense yellow oil. ${ }^{1} \mathrm{H}$ NMR $\left(400 \mathrm{MHz}, \mathrm{CD}_{3} \mathrm{OD}\right)$

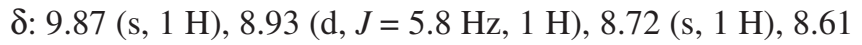
(d, $J=7.3 \mathrm{~Hz}, 2 \mathrm{H}), 7.92(\mathrm{t}, J=7.4 \mathrm{~Hz}, 1 \mathrm{H}), 4.14(\mathrm{~s}, 1 \mathrm{H})$, $3.78(\mathrm{~d}, J=11 \mathrm{~Hz}, 1 \mathrm{H}), 3.66-3.50$ (m, $1 \mathrm{H}), 3.40$ (d, $J=16.5$ $\mathrm{Hz}, 2 \mathrm{H}), 2.18-1.56$ (m, $5 \mathrm{H}) .{ }^{13} \mathrm{C} \mathrm{NMR}\left(100 \mathrm{MHz}, \mathrm{CD}_{3} \mathrm{OD}\right)$

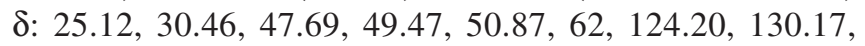
131.45, 134.51, 136.13, 136.72, 137.68, 140.17, 149.80.

(R)-6H-1-(5-Isoquinolinesulfonyl)-2-carboxyl-1-pyrrolidine (4\#): Isoquinoline sulfonyl chloride hydrochloride (2 $\mathrm{g}, 7.60 \mathrm{mmol}$ ) was dissolved in $25 \mathrm{~mL}$ ice water to keep the temperature at $0-5{ }^{\circ} \mathrm{C}$. To solution of isoquinoline sulfonyl chloride hydrochloride was added dropwise to L-proline ( $1 \mathrm{~g}$, $8.69 \mathrm{mmol})$ and sodium carbonate $(1.11 \mathrm{~g}, 10.4 \mathrm{mmol})$ in 25 $\mathrm{mL}$ ice water. The reaction was keep to $0-5{ }^{\circ} \mathrm{C}$ for $2 \mathrm{~h}$. The aqueous layer was concentrated. The residue was extracted with $30 \mathrm{~mL} \mathrm{CH}_{3} \mathrm{OH}$. The crude was purified by flash chromatography (ethyl acetate) to afford compound 4 (0.23 g, $14 \%)$ dense yellow oil; ${ }^{1} \mathrm{H} \mathrm{NMR}\left(600 \mathrm{MHz}, \mathrm{CDCl}_{3}\right) \delta: 9.47(\mathrm{~s}, 1 \mathrm{H})$, 8.87-8.62 (d, $J=9.6 \mathrm{~Hz}, 2 \mathrm{H}), 8.67$ (s, 1H), 8.55 (d, $J=10.8$ $\mathrm{Hz}, 1 \mathrm{H}), 8.37(\mathrm{~s}, 1 \mathrm{H}), 7.86(\mathrm{t}, J=11.7 \mathrm{~Hz}, 1 \mathrm{H}), 4.27$ (t, $J=$ $11.4 \mathrm{~Hz}, 1 \mathrm{H}), 3.5(\mathrm{~m}, 1 \mathrm{H}), 2.47-2.45(\mathrm{~m}, 2 \mathrm{H}), 2.16-2.13(\mathrm{~m}$, 2H), 2.13-2.09 (m, 2H). ${ }^{13} \mathrm{C} \mathrm{NMR}\left(150 \mathrm{MHz}, \mathrm{CDCl}_{3}\right) \delta: 25.86$, 32.25, 53.44, 61.93, 123.94, 130.04, 131.25, 135.25, 136.27, 137.76, 139.81, 149.95, 174.07, 175.26.

(S)-6H-1-(5-Isoquinolinesulfonyl)-2-carboxyl-1pyrrolidine (5\#): Following similar compound 4 procedure, compound 5 was prepared from D-proline. The crude was purified by flash chromatography (ethyl acetate) to afford compound 5 (0.23 g, $14 \%)$ dense yellow oil; ${ }^{1} \mathrm{H}$ NMR (600 $\left.\mathrm{MHz} \mathrm{CDCl}_{3}\right) \delta: 9.47$ (s, 1H), 8.87-8.82 (d, $\left.J=9.6 \mathrm{~Hz}, 2 \mathrm{H}\right)$, $8.67(\mathrm{~s}, 1 \mathrm{H}), 8.55(\mathrm{~d}, J=10.8 \mathrm{~Hz}, 1 \mathrm{H}), 8.37(\mathrm{~s}, 1 \mathrm{H}), 7.86(\mathrm{t}$, $J=11.7 \mathrm{~Hz}, 1 \mathrm{H}), 4.27(\mathrm{t}, J=11.4 \mathrm{~Hz}, 1 \mathrm{H}), 3.5(\mathrm{~m}, 1 \mathrm{H}), 2.47-$ 2.45 (m, 2 H), 2.16-2.13 (m, 2H), 2.13-2.09 (m, 2H). ${ }^{13} \mathrm{C} \mathrm{NMR}$

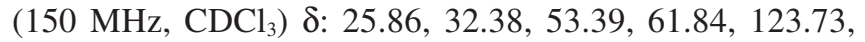
$130.04,131.25,135.25,136.17,137.62,139.76,149.92$, 174.07, 175.26.

(R)-6H-1-(5-Isoquinolinesulfonyl)-2-fluorinatedmethyl-1-pyrrolidine (6\#): To a solution of methanesulfonyl chloride (1.71 g , $15 \mathrm{mmol}$ ) was added dropwise to (R)-6H-1(5-isoquinolinesulfonyl)-2-hydroxymethyl-1-pyrrolidine (3.80 g, $13 \mathrm{mmol})$ and triethylamine $(1.85 \mathrm{~g}, 18.3 \mathrm{mmol})$ in $40 \mathrm{~mL}$ dichloromethane. The reaction mixture was stirred at $0-5{ }^{\circ} \mathrm{C}$ for $2 \mathrm{~h}$. The organic layer was washed with $20 \mathrm{~mL}$ water for twice. And then the organic layer was dried and concentrated, afford yellow oil $(4.30 \mathrm{~g}, 90.3 \%)$; to solution the tetrabutylammonium fluoride $(1.88 \mathrm{~g}, 7.2 \mathrm{mmol})$ was added dropwise to the yellow oil $(4.30 \mathrm{~g}, 11.6 \mathrm{mmol})$ dissolved in $30 \mathrm{~mL}$ tetrahydrofuran. The reaction mixture was stirred at 65 ${ }^{\circ} \mathrm{C}$ for $8 \mathrm{~h}$ and then tetrabutylammonium fluoride was distilled. The crude was purified by flash chromatography (ethyl acetate: petroleum ether $=2: 1, \mathrm{v} / \mathrm{v})$ to afford compound $6(0.92 \mathrm{~g}, 27$ $\%)$ dense yellow oil; m.p.: 178.2-179.1 ${ }^{\circ} \mathrm{C} .{ }^{1} \mathrm{H}$ NMR $(600 \mathrm{MHz}$, $\left.\mathrm{CDCl}_{3}\right) \delta: 10.23(\mathrm{~d}, J=10.7 \mathrm{~Hz}, 1 \mathrm{H}), 9.25(\mathrm{~d}, J=6.8 \mathrm{~Hz}, 1 \mathrm{H})$, 8.97-8.65 (m, 2H), 8.11 (t, J=7.8 Hz, 1H), $7.28(\mathrm{~s}, 1 \mathrm{H}), 4.34$ (m, 1H), 4.20 (m, 1H), 3.75-3.67 (m, 2H), 2.13-2.10 (m, 2H), 
$1.52-1.03(\mathrm{t}, J=5.4 \mathrm{~Hz}, 1 \mathrm{H}) .{ }^{13} \mathrm{C} \mathrm{NMR}\left(150 \mathrm{MHz}, \mathrm{CDCl}_{3}\right) \delta$ : 25.13, 30.44, 47.73, 50.90, 61.96, 123.95, 130.19, 131.29, $135.09,135.89,136.53,137.63,139.94,150.05$.

(S)-4-Hydroxyl-(2-carboxyl-pyrrolidine-1-sulfonyl)isoquinoline (7\#): Compound 7 was similarly prepared from trans-4-hydroxy-L-proline in $46 \%$ yield. ${ }^{1} \mathrm{H}$ NMR $(600 \mathrm{MHz}$, $\left.\mathrm{D}_{2} \mathrm{O}\right) \delta: 9.36(\mathrm{~s}, 1 \mathrm{H}), 8.78(\mathrm{~s}, 1 \mathrm{H}), 8.76(\mathrm{~s}, 1 \mathrm{H}), 8.58-8.62(\mathrm{~d}$, $J=9.6 \mathrm{~Hz}, 2 \mathrm{H}), 7.82(\mathrm{~d}, J=11.4 \mathrm{~Hz}, 1 \mathrm{H}), 4.27(\mathrm{t}, J=11.4$ $\mathrm{Hz}, 1 \mathrm{H}), 3.63$ (s, 1H), 3.40-3.32 (m, $2 \mathrm{H}), 2.13-2.11$ (m, 2H). ${ }^{13} \mathrm{C}$ NMR (150 MHz, $\left.\mathrm{D}_{2} \mathrm{O}\right) \delta: 26.34,30.65,51.97,71.51$, $128.73,130.04,133.25,135.25,136.17,137.62,142.76$, 150.92, 176.07, 179.26.

BV-2 microglia cell materials: Culture of BV-2 cells: rat BV-2 microglia cell lines were bought from American Type Culture Collection (ATCC) and subcultured by Professor Xiao's laboratory. BV-2 microglia cells were initially seeded at $1 \times 105 \mathrm{~mL}$ cells into DMEM culture dish $\left(10 \mathrm{~cm}^{2}\right)$, DMEM nutrient solution containing $10 \%$ FBS was added to them, which were cultured and subcultured at $37{ }^{\circ} \mathrm{C}$ in $5 \% \mathrm{CO}_{2}$ atmosphere.

Primary neurons culture: Mouse cortex from 16-18 embryonic day old mice was dissected under a microscope and then dissociated in neurobasal medium (Gibco) containing $2 \%$ B27 (Gibco). $100 \mu \mathrm{g} / \mathrm{mL}$ streptomycin and $100 \mathrm{U} / \mathrm{mL}$ penicillin (Gibco) were then added to tissue samples. Blood vessels and other fibres were removed by filtration using a 40 $\mu \mathrm{m}$ sterile nylon filter. The cell suspension $\left(1 \times 10^{6} \mathrm{cells} / \mathrm{cm}^{2}\right)$ was then plated onto flasks coated with poly-D-lysine $(0.1$ $\mathrm{mg} / \mathrm{mL}$, Sigma). Primary neurons were cultured at $37^{\circ} \mathrm{C}$ in a humidified cell incubator under $5 \% \mathrm{CO}_{2}$ for approximately 7-10 days. Primary neurons were cultured at $37^{\circ} \mathrm{C}$ in a humidified cell incubator under $5 \% \mathrm{CO}_{2}$ for approximately 7-10 days. Primary neurons were then cultured for $24 \mathrm{~h}$ in the presence of fasudil and compounds $\mathbf{1 - 8}(15 \mu \mathrm{g} / \mathrm{mL})$.

ROCK activity assay: ROCK activity was measured using the CycLex Research Product ROCK assay kit (cat. \# CY-1160). It has been used to determine ROCK activity in cell extracts and tissue cytosol (CycLex Co., Ltd, Nagano, Japan). BV-2 microglial cells were homogenized on ice in four volumes of an appropriate extraction buffer $(\mathrm{pH} \mathrm{8)}$, which included $0.1 \%$ triton $\mathrm{X}-100,50 \mathrm{mM}$ tris- $\mathrm{HCl}, 1 \mathrm{mM}$ EGTA, $1 \mathrm{mM}$ EDTA, $10 \mathrm{mM} \mathrm{NaF}, 0.5 \mathrm{mM}$ PMSF and $10 \mathrm{mM} \beta-$ mercapto-ethanol. BV-2 microglial cells were then centrifuged for $0.5 \mathrm{~h}$ to collect the supernatant. Protein concentration was determined by a BicinChoninic acid protein assay kit (Pierce, USA). ROCK activity in the supernatant fraction $(100 \mu \mathrm{L}$ fraction containing $50 \mathrm{ng}$ protein) was determined following the manufacturer's instructions. Optical density was measured at $490 \mathrm{~nm}$. Experiments were also performed in the presence of Fasudil and the synthesised compounds $(10 \mu \mathrm{g} / \mathrm{mL})$ for $24 \mathrm{~h}$.

3-[4,5-Dimethyltyhiazol-2-yl]-2,5-diphenyl tetrazolium bromide assays: Cell viability was assessed by [3-(4,5dimethylthiazol-2-yl)-2,5-diphenyltetrazolium bromide] assay ${ }^{19}$. Cells were seeded $(100 \mu \mathrm{L}$ BV-2 microglial cell suspension) at a cell density of $1 \times 10^{4}$ cells/well onto 96-well plates and kept overnight. Fasudil and synthesized compounds $(15 \mu \mathrm{g} / \mathrm{mL})$ were added for $24 \mathrm{~h}$. The medium was removed and the cells were incubated in FBS-free medium containing
$0.5 \mathrm{mg} / \mathrm{mL}$ MTT. After an incubation period of $4 \mathrm{~h}$ at $37^{\circ} \mathrm{C}$, the medium was discarded. Formazan blue that formed in the cells was dissolved in DMSO and the optical density was measured at $490 \mathrm{~nm}$. All cell culture experiments were performed in triplicate and repeated at least three times.

Lactate dehydrogenase assays: Cell death was measured by lactate deyhydrogenase release in culture medium ${ }^{20,21}$. Levels of LDH release in supernatants of BV-2 microglial cells were measured with a cytotoxicity detection kit (Promega) according to the manufacturer's protocol. The optical density was measured at $490 \mathrm{~nm}$. Maximum LDH release assessed by freeze-thaw lysing of normal culture cells was considered as control value (100\% LDH release). Data were expressed as a percentage of the control value.

\section{RESULTS AND DISCUSSION}

Fasudil, the only marketed Rho kinase inhibitor, as the reference compound, homopiperazine of Fasudil were replaced by pyrrolidine. Seven isoquinoline Rho kinase inhibitors were designed and synthesized. These compounds were fully characterized by ${ }^{1} \mathrm{H}$ and ${ }^{13} \mathrm{C}$ NMR spectroscopy, IR and high-resolution mass-spectrometry. Their biological activity including Rho kinase inhibitory activity, the cell viability were systematically evaluated as shown in the following (Scheme-I).

Rho kinase inhibitory activity: The evaluation results are shown in Fig. 2, it was found that compounds 2, 3, 6 have shown excellent inhibitory abilities. The hydroxy group within compound $\mathbf{2}$ is of great importance for the formation of hydrogen bond and of help for improving the Rho Rho kinase inhibitory activity. Compounds 3, 6 existing chlorine and fluorine to be hydroxyl's isosteres, also gave rise to excellent results. Compounds 4, 5, 7 gave rise to poor results and we speculate that the carboxyl, exhibiting the acid, brought about the poor results. As we known, the hydroxyl Fasudil exhibited much higher Rho kinase inhibitory activity comparing to Fasudil in vivo. The compound $\mathbf{1}$, as the hydroxyl Fasudil intermediates, however, the Rho kinase inhibitory activity is not very well.

Determination of cell viability by MTT assay (primary neuronal cells and BV-2 microglia cells): According to the Fig. 3a, it could be seen that compound $\mathbf{6}$ could exhibit better ability than fausdil. Compound $\mathbf{1}$ are inferior to fasudil. Importantly, compounds 2, 5, 7 exhibited the similar ability with fasudil. Then, we examined the concentration effect of the activity of all the compounds (Fig. 3b). Results exhibited that Fasudil in high concentration $(50 \mu \mathrm{g} / \mathrm{mL})$ caused the obvious activity. By contrast, the activity of compound $\mathbf{6}$ did not change in low concentration, while at medium and high concentration the activity enhanced obviously. The changes, which were low concentration to high concentrations, were not obvious.

As shown in Fig. 4a, it could be seen that the compounds 2, 6, exhibit a slight increase than other compounds. Therefore, it is speculated that no obvious effect on BV-2 microglia cells. In Fig. 4b, fasudil increased to $50 \mu \mathrm{g} / \mathrm{mL}$ could obviously inhibit the activity, while the compound 6 in high concentration $(50 \mu \mathrm{g} / \mathrm{mL})$ leaded to enhance activity. The rest of the compounds from low concentration to high concentration had no obvious influence. 


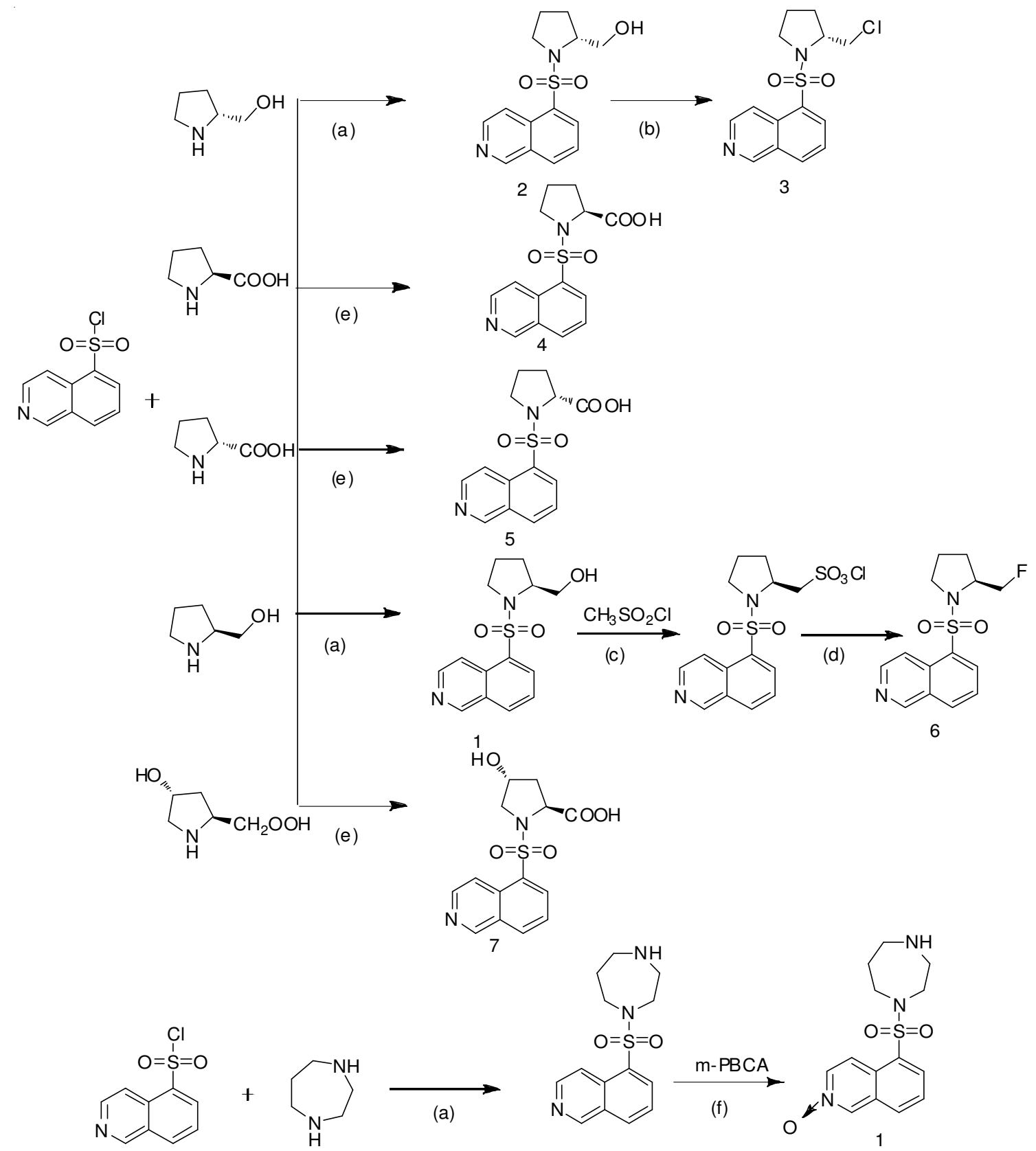

Scheme-I: Synthesis of compounds 1-7; (a) $\mathrm{CH}_{2} \mathrm{Cl}_{2}, 0{ }^{\circ} \mathrm{C}, 2 \mathrm{~h}, 95 \%$ yield; (b) $\mathrm{SOCl}_{2}, 40{ }^{\circ} \mathrm{C}, 8 \mathrm{~h}, 75 \%$ yield; (c) $\mathrm{CH}_{2} \mathrm{Cl}_{2}, \mathrm{CH}_{3} \mathrm{SO}_{2} \mathrm{Cl}, 0{ }^{\circ} \mathrm{C}, 2 \mathrm{~h}, 90 \%$ yield; (d) THF, $\left(\mathrm{CH}_{3}\right)_{4} \mathrm{NF}, 65^{\circ} \mathrm{C}, 8 \mathrm{~h}, 27 \%$ yield; (e) $\mathrm{H}_{2} \mathrm{O}, \mathrm{Na}_{2} \mathrm{CO}_{3}, 0{ }^{\circ} \mathrm{C}, 2 \mathrm{~h}, 44 \%$ yield; (f) m-PBCA, r.t. $1 \mathrm{~h}, 82.17 \%$ yield

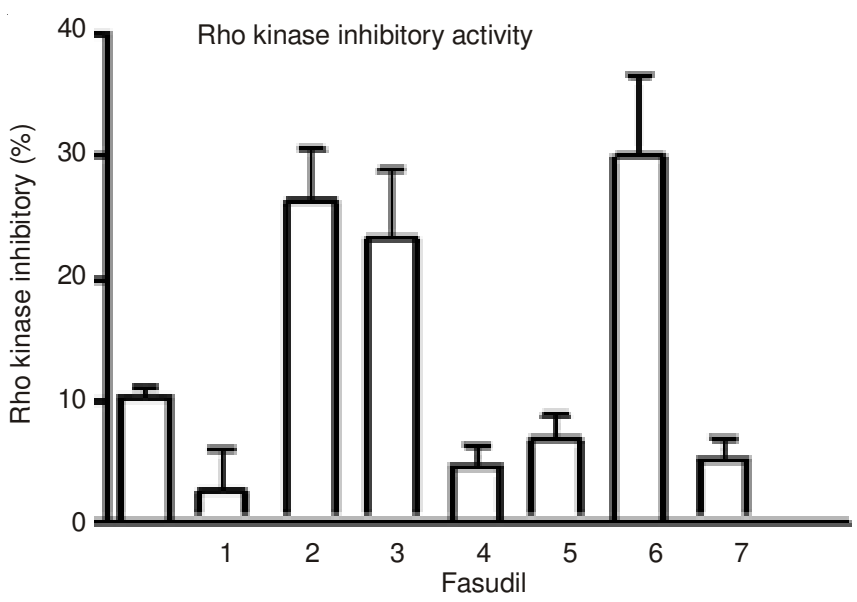

Fig. 2. ROCK kinase inhibitory activity of BV-2 microglial cells treated with Fasudil and compounds 1-7 $(10 \mu \mathrm{g} / \mathrm{mL})$

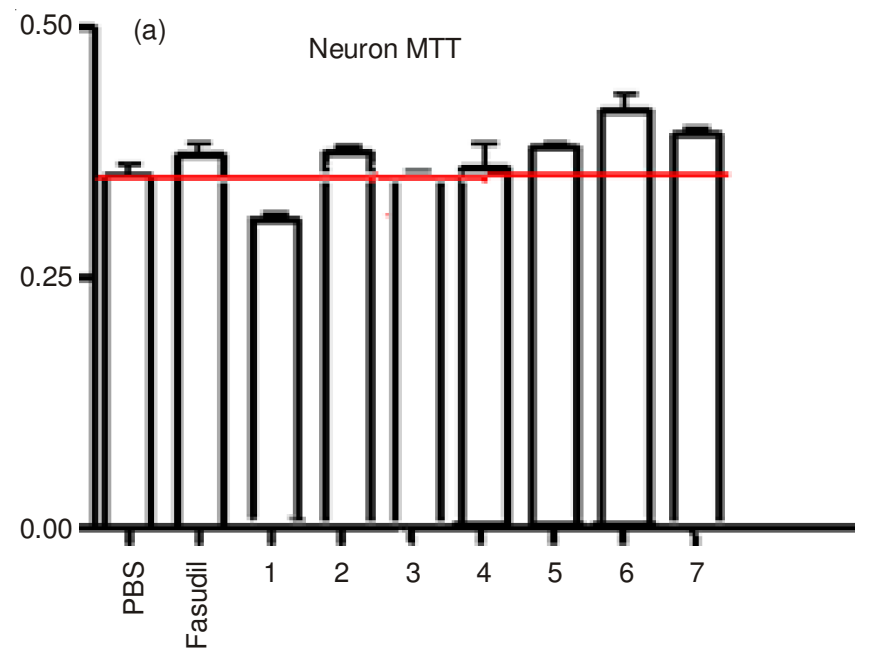




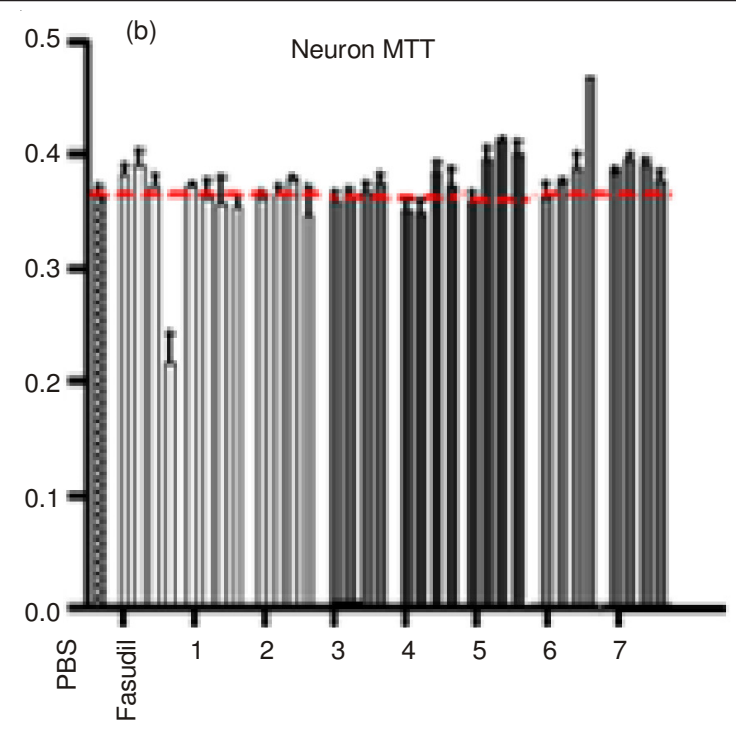

Fig. 3. Determination of cell viability by MTT assay (Primary neurons). Primary neurons cultured with Fasudil and compounds 1-7; (a) 15 $\mu \mathrm{g} / \mathrm{mL}$; (b) the concentration is $1,5,15$ and $50 \mu \mathrm{g} / \mathrm{mL}$. All data represent means \pm standard deviations (error bars) for three separate experiments
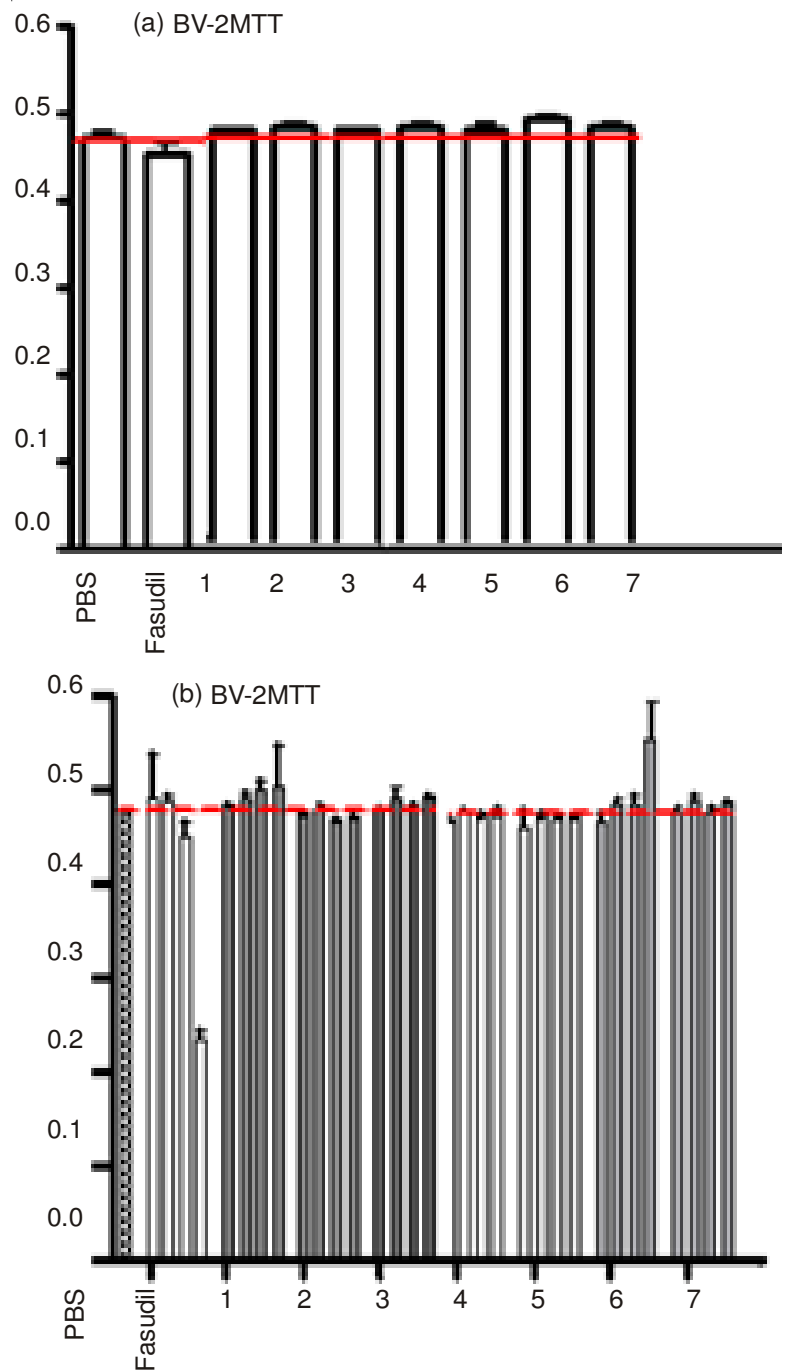

Fig. 4. Determination of cell viability by MTT assay (BV-2 microglia) BV-2 microglia cultured with Fasudil and compounds 1-7; (a) 15 $\mu \mathrm{g} / \mathrm{mL}$ (b) the concentration is $1,5,15$ and $50 \mu \mathrm{g} / \mathrm{mL}$. All data represent means \pm standard deviations (error bars) for three separate experiments
Determination of cell viability by LDH assay (primary neuronal cells and BV-2 microglia cells): Compared with the PBS treatment, compounds $\mathbf{2}, \mathbf{3}$ and $\mathbf{6}$ exhibited less toxicity than fasudil (Fig. 5a). Meanwhile, compound 1 released more toxicity than fasudil. Other compounds released similar toxicity with Fasudil. Compounds 2, 6 could form hydrogen bonds with Region D of the Rho kinase, which resulted in higher cell viability. Compound $\mathbf{3}$ existing heteroatom chloro, to be hydroxyl's isosteres, also gave rise to excellent results. As seen in Fig. 5b, fasudil $(50 \mu \mathrm{g} / \mathrm{mL})$ had high cytotoxicity, while compounds $\mathbf{2}$ and $\mathbf{6}$ in high concentrations not merely mediated cytotoxicity, instead, they protected primary neurons to some degree.
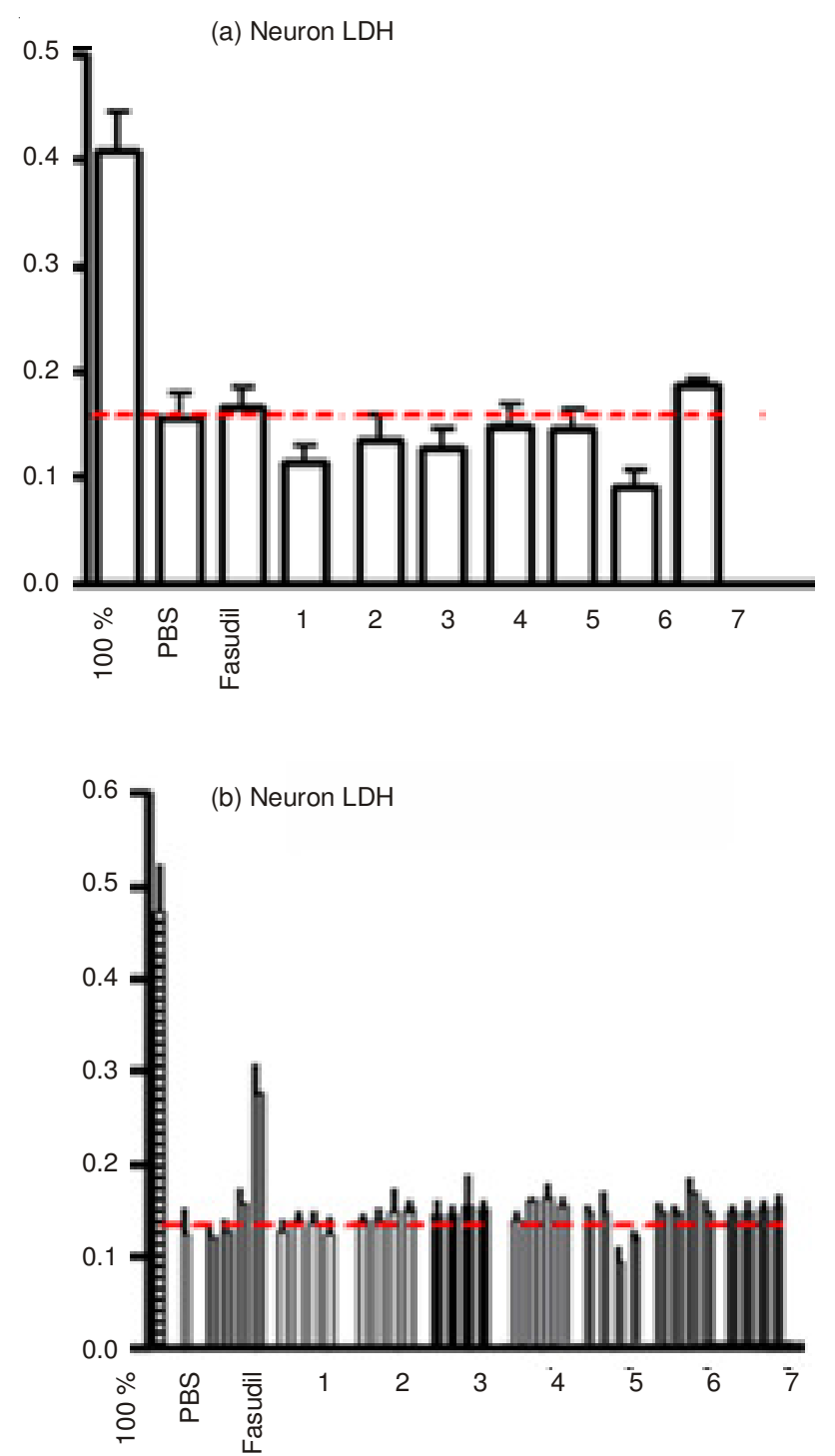

Fig. 5. Determination of cell viability by LDH assay (primary neurons). Primary neurons cultured with Fasudil and compounds 1-7; (a) 15 $\mu \mathrm{g} / \mathrm{mL}$ (b) The concentration is $1,5,15$ and $50 \mu \mathrm{g} / \mathrm{mL}$. All data represent means \pm standard deviations (error bars) for three separate experiments

As seen in Fig. 6a, compounds $\mathbf{2}, \mathbf{3}$ and $\mathbf{6}$ had the lower cytotoxicity and fasudil was the highest toxicity. The rest of the compounds showed less toxicity than fasudil. As the further experiment, we performed the concentration effect of toxicity 
(Fig. 6b). Results exhibited that compound 6 high concentration $(50 \mu \mathrm{g} / \mathrm{mL})$ could reduce the toxicity. But Fasudil in high concentration $(50 \mu \mathrm{g} / \mathrm{mL})$ caused more obvious cytotoxicity.
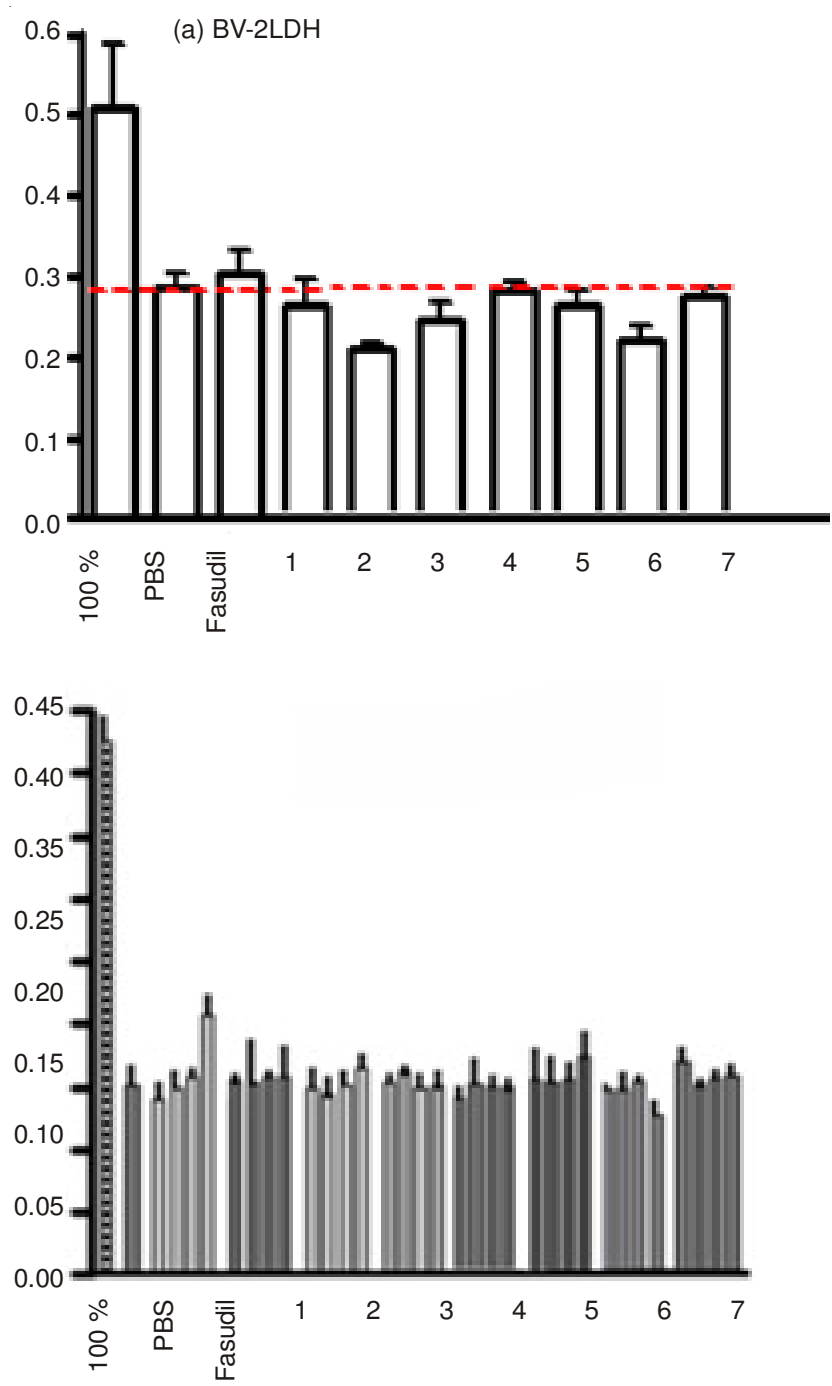

Fig. 6. Determination of cell viability by LDH assay. BV-2 microglia Cells cultured with Fasudil and compounds 1-7; (a) $15 \mu \mathrm{g} / \mathrm{mL}$ (b) The concentration is $1,5,15$ and $50 \mu \mathrm{g} / \mathrm{mL}$. All data represent means \pm standard deviations (error bars) for three separate experiments

\section{Conclusion}

Seven fasudil derivatives were designed and synthesized. Their biological activities were systematically evaluated, including Rho kinsase inhibitory activity, cell viability. Compounds 2, $\mathbf{3}$ and $\mathbf{6}$ have better inhibitory activities of Rho kinase, excellent biological activity and lower side effects than fasudil. From the structures of compounds, it was found that hydroxyl and halogen, considered as receptors, of hydrogen bond between an inhibitor and kinase at the $\mathrm{D}$ region, which effectively improve the inhibitory and bioactive abilities of Rho kinase. The further studies towards compounds 2, 3 and $\mathbf{6}$ are current under investigation.

\section{REFERENCES}

1. J.K. Liao, M. Seto and K. Noma, J. Cardiovasc. Pharmacol., 50, 17 (2007).

2. I.A. Abdel-Hamid, Drug Discov. Today, 10, 1459 (2005).

3. A. Masumoto, M. Masahiro, H. Shimokawa, L. Urakami, M. Usui and A. Takeshita, Circulation, 105, 1545 (2002).

4. V.P. Rao and D.L. Epstein, Bio. Drugs, 21, 167 (2007).

5. H. Tokushige, M. Inatani, S. Nemoto, H. Sakaki, K. Katayama, M. Uehata and H. Tanihara, Invest. Ophthalmol. Vis. Sci., 48, 3216 (2007).

6. I. Cicha, M. Goppelt-Struebe, S. Muehlich, A. Yilmaz, D. Raaz, W.G. Daniel and C.D. Garlichs, Atherosclerosis, 196, 136 (2008).

7. M. Kobayashi, H. Kume, T. Oguma, Y. Makino, Y. Ito and K. Shimokata, Clin. Exp. Allergy, 38, 135 (2008).

8. B.K. Mueller, H. Mack and N. Teusch, Nat. Rev. Drug Discov., 4, 387 (2005).

9. L. Yin, K. Morishige, T. Takahashi, K. Hashimoto, S. Ogata, S. Tsutsumi, K. Takata, T. Ohta, J. Kawagoe, K. Takahashi and H. Kurachi, Mol. Cancer Ther., 6, 1517 (2007).

10. K. Noma, N. Oyama and J.K. Liao, Am. J. Physiol. Cell Physiol., 290, 661 (2005).

11. M. Iwakubo, A. Takami, Y. Okada, T. Kawata, Y. Tagami, H. Ohashi, M. Sato, T. Sugiyama, K. Fukushima and H. Iijima, Bioorg. Med. Chem., 15, 350 (2007).

12. P. Lingor, L. Tonges, N. Pieper, C. Bermel, E. Barski, V. Planchamp and M. Bahr, Brain, 131, 250 (2008).

13. I. Barbaric, M. Jones, D.J. Harley, P.J. Gokhale and P.W. Andrews, J. Biomol. Screen., 16, 603 (2011).

14. A. Tura, F. Schuettauf, P.P. Monnier, K.U. Bartz-Schmidt and S. HenkeFahle, Invest. Ophthalmol. Vis. Sci., 50, 452 (2008).

15. K. Yamashita, Y. Kotani, Y. Nakajima, M. Shimazawa, S. Yoshimura, S. Nakashima, T. Iwama and H. Hara, Brain Res., 1154, 215 (2007).

16. L. Tonges, T. Frank, L. Tatenhorst, K.A. Saal, J.C. Koch, E.M. Szego, M. Bahr, J.H. Weishaupt and P. Lingor, Brain, 135, 3355 (2012).

17. S. Satoh, T. Utsunomiya, K. Tsurui, T. Kobayashi, I. Ikegaki, Y. Sasaki and T. Asano, Life Sci., 69, 1441 (2001).

18. T. Asano, I. Ikegaki, S. Satoh, Y. Suzuki, M. Shibuya, M. Takayasu and H. Hidaka, J. Pharmacol. Exp. Ther., 241, 1033 (1987).

19. K. Berg, M.B. Hansen and S.E. Nielsen, APMIS, 98, 156 (1990).

20. V. Geaugey, F. Pascal, J.M. Engasser and A. Marc, Biotechnol. Technol., 4, 257 (1990).

21. C. Baba, K. Yanagida, T. Kanzaki and M. Baba, Antivir. Chem. Chemother., 16, 33 (2005). 